\title{
President's Message: 50 Years
}

Andromeda Yelton

Fifty years.

LITA was voted into existence (as ISAD, the Information Science and Automation Division) in Detroit at Midwinter 1966. Therefore we have just completed our first fifty years, a fact celebrated (thanks to our 50th Anniversary Task Force) with a slide show and cake at Annual in Chicago. It's truly humbling to take office upon this milestone.

Looking back, some of the true giants of library technology have held this office. In 1971-72, Jesse Shera, who in his wide-ranging career challenged librarians to think deeply about the epistemological and sociological dimensions of librarianship; ALA makes several awards in his name today. In 1973-74 and again in 1974-75, Frederick Kilgour, the founding director of OCLC, who also has an eponymous award. In 1975-76, Henriette Avram, the mother of MARC, herself.

Moreover, thanks to the work of countless LITA volunteers, much of this history is available openaccess. I strongly recommend reading http://www.ala.org/lita/about/history/for an overview of the remarkable people and key issues across our history. You can also read papers by Avram and Kilgour, among many others, in the archives of this very publication.

In fact, reading the ITAL archives is deeply engaging. It turns out library technology has changed a bit in 50 years! (I trust that isn't a shock to you.) The first articles (in what was then the Journal of Library Automation) are all about instituting first-time computer systems to automate traditional library functions such as acquisitions, cataloging, and finance. The following passage caught my eye:

"A functioning technical processing system in a two-year community college library utilizes a model 2201 Friden Flexowriter with punch card control and tab card reading units, an IBM 026 Key Punch, and an IBM 1440 computer, with two tape and two disc drives, to produce all acquisitions and catalog files based primarily on a single typing at the time of initiating an order" ("An Integrated Computer Based Technical Processing System in a Small College Library", Jack W. Scott; https://doi.org/10.6017/ital.v1i3.2931.)

How many of us are still using punch cards today? And, indeed, how many of us are automating libraries for the first time? The topics discussed among LITA members today are far more wideranging: user experience, privacy, accessibility. They're more likely to be about assessing and improving existing systems than creating new ones, and more likely to center on patron-facing technologies.

Andromeda Yelton (andromeda.yelton@gmail.com) is LITA President 2017-18 and owner/consultant of Small Beautiful Useful LLC. 
And yet, with a few substitutions - say, "Raspberry Pi" for "Friden Flexowriter" — the blockquote above would not be out of place today. Then as now, LITA members were doing something exciting, yet deeply practical, that cleverly repurposes new technology to make library experiences better for both patrons and staff.

Our job descriptions have changed enormously in fifty years; in fact, the LITA Board charged a task force to develop LITA member personas, so that we can better understand whom we serve, and work to align our publications, online education, conference programming, and committee work toward your needs. (You can see an overview of the task force's stellar work on LITAblog: http://litablog.org/2017/03/who-are-lita-members-lita-personas/.)

At the same time, the spirit of pragmatic creativity that runs throughout the first issues of the Journal of Library Automation continues to animate LITA members today. I'm looking forward to seeing where we go in our next fifty years. 